\title{
Full scale amendment of a contaminated wood impregnation site with iron water treatment residues
}

Nielsen, Sanne Skov; Kjeldsen, Peter; Jakobsen, Rasmus

Published in:

Frontiers of Environmental Science \& Engineering

Link to article, DOI:

10.1007/s11783-016-0842-1

Publication date:

2016

Document Version

Peer reviewed version

Link back to DTU Orbit

Citation (APA):

Nielsen, S. S., Kjeldsen, P., \& Jakobsen, R. (2016). Full scale amendment of a contaminated wood impregnation site with iron water treatment residues. Frontiers of Environmental Science \& Engineering, 10(4), 1-10. [03]. https://doi.org/10.1007/s11783-016-0842-1

\section{General rights}

Copyright and moral rights for the publications made accessible in the public portal are retained by the authors and/or other copyright owners and it is a condition of accessing publications that users recognise and abide by the legal requirements associated with these rights.

- Users may download and print one copy of any publication from the public portal for the purpose of private study or research.

- You may not further distribute the material or use it for any profit-making activity or commercial gain

- You may freely distribute the URL identifying the publication in the public portal 
Full scale amendment of a contaminated wood impregnation site with iron water treatment residues

2

3 Sanne Skov Nielsen ${ }^{\text {a)}}$, Peter Kjeldsen( $\left.₫\right)$, Rasmus Jakobsen ${ }^{\text {b) }}$

4 Department of Environmental Engineering, Technical University of Denmark, Miljovej 113, DK-2800 Kgs.

5 Lyngby, Denmark

6 e-mail: pekj@env.dtu.dk

$8(\square)$ Corresponding author:

9 Peter Kjeldsen

10 Tel. +4545251561

11 Fax. +4545932850

12 e-mail: pekj@env.dtu.dk

a) Present address: Orbicon, Ringstedvej 20, DK-4000 Roskilde, Denmark (e-mail: sann@orbicon.dk)

b) Present address: Geological Survey of Denmark and Greenland, Geological Survey of Denmark and Greenland, Øster Voldgade 10, DK-1350 Copenhagen K, Denmark (e-mail: raj@geus.dk)

\begin{abstract}
Iron water treatment residues (Fe-WTR) are a free by-product of the treatment of drinking water with high concentration of iron oxides and potential for arsenic sorption. This paper aims at applying Fe-WTR to a contaminated site, measuring the reduction in contaminant leaching, and discussing the design of delivery and mixing strategy for soil stabilization at field scale and present a cost-effective method of soil mixing by common contractor machinery. Soil contaminated by $\mathrm{As}, \mathrm{Cr}$, and $\mathrm{Cu}$ at an abandoned wood impregnation site was amended with $0.22 \%(\mathrm{dw})$ Fe-WTR. To evaluate the full scale amendment a $100 \mathrm{~m}^{2}$ test site and a control site (without amendment) were monitored for 14 months. Also soil analysis of Fe to evaluate the degree of soil and Fe-WTR mixing was done. Stabilization with Fe-WTR had a significant effect on leachable contaminants, reducing pore water As by $93 \%$, Cu by $91 \%$ and $\mathrm{Cr}$ by $95 \%$ in the upper samplers. Dosage and mixing of Fe-WTR in the soil proved to be difficult in the deeper part of the field, and pore water concentrations of arsenic was generally higher. Despite water logged conditions no increase in dissolved iron or arsenic was observed in the amended soil. Our field scale amendment of contaminated soil was overall successful in decreasing leaching of $\mathrm{As}, \mathrm{Cr}$ and $\mathrm{Cu}$. With minor improvements in the mixing and delivery strategy, this stabilization method is suggested for use in cases, where leaching of $\mathrm{Cu}$, Cr and As constitutes a risk for groundwater and freshwater.
\end{abstract}

Keywords Field experiment, Iron oxide, Metal, Stabilization, Wood preservation sites Running title: Amendment of a wood impregnation site with iron water treatment residues 


\section{$1 \quad$ Introduction}

Throughout Europe brownfields are present as remnants of industrial production. As early industrial sites from a time with no environmental protection laws, the sites may be heavily contaminated, and often the contamination consists of heavy metals, that are, by nature, not degradable in the environment. The sheer volume of soil is frequently too large for excavation and when the sites are situated in isolated locations, development is not economically feasible. These sites may pose a threat to aquifers and surface waters by leaching of contaminants. Cleaning and reutilization technologies of metal(loid) polluted soils including soil washing [1, electrochemical remediation [2], phytoremediation [3] and combinations thereof are only scarcely used [4].

Stabilizing or amending metal(loid) contaminated soil involves adding an amendment to the contaminated soil layers that reduces leaching of contaminants from the soil by sorption or precipitation, and is useful for brownfields and cases where there are no special requirements for the land use. In cases where such circumstances can be fulfilled, the method is considered a cost effective way to minimize the impact of mobile element contamination on the recipients [5]. Bioavailability of contaminants at the site may also be limited $[5,6]$ which prevents spreading of contaminants in the food chain.

At former wood impregnation sites especially arsenic (As) is often very mobile in soil and groundwater systems [7,8]. Iron oxides have a strong affinity for arsenic and other trace elements $[9,10]$ and several iron oxides has been evaluated as soil amendment for reducing arsenic and heavy metal leachability: Ochre from mining activities [11], goethite [12], and water treatment residues [13,14]. In cases of multi element contamination a mix of amendments may prove the best option and can be assessed in a strategic selection framework [15]. However, the long-term ability of the amendment to reduce leachability should also be considered since slow transformation of the reactive minerals to less reactive minerals may occur over longer time [16,17].

Iron water treatment residues (Fe-WTR) are a common waste product in Denmark, where the water supply is based entirely on groundwater. With the main constituent (60-70\%) being ferrihydrite, an iron hydroxide, it is proposed here as a cheap and efficient soil amendment. No pH buffers are required as for iron(II)sulphate, and the cost is limited to a control element analysis and transport to the site. Numerous laboratory studies with soil amendments using iron oxides have been carried out, but few have tested the methods at field scale [14,18] and applicability has not been discussed and evaluated. Laboratory experiments are often carried out under optimal conditions, and their results may not directly be transferred to full-scale scenarios in the field. Also impacts on the soil amendment such as geochemical processes in the soil influenced by soil moisture and biota are lacking in laboratory experiments. For iron oxide amendments prone to microbial iron reduction it is necessary to test their persistency under natural conditions.

For full scale amendments large areas need to be treated so choosing a cost-effective and simple way to mix the treated soil and the amendment is crucial. In considering the options for soil mixing, the depth of the contaminated soil layers to be treated is an important factor. Soil mixing by augers is routinely 
used in the delivery of zero valent iron (ZVI)-clay mixtures for degradation of chlorinated solvents [19] at depths down to $8 \mathrm{~m}$ below ground. However, the equipment is highly specialized and therefore expensive to rent. Trench ploughing, with a common use in forestry and a working depth of about $0.9 \mathrm{~m}$, is an option, but the trench plough has a considerable turning radius and will only reach the maximum working depth after $50 \mathrm{~m}$ of ploughing. Another option is to use a screening bucket, a tool used in waste management and soil treatment at construction sites. A screening bucket consists of a screen, capable to hold about $0.5 \mathrm{~m}^{3}$ of soil that is passed through the screen by rotating it. Soil fractions $>50 \mathrm{~mm}$ (usually stones, but for fill also bricks and concrete pieces) is then retained inside the screen and can be discarded. Adding Fe-WTR as slurry, soil and slurry mixture would pass faster through the screening bucket.

This study evaluates the full scale amendment with Fe-WTR at a brownfield contaminated with high levels of As, chromium (Cr) and copper (Cu). To our knowledge this is a novel technology, not tested at full scale before. In designing the full scale approach, emphasis was put on making a low cost method easily applicable to a brownfield, thereby maximizing the options for wide-spread professional use. For evaluation of the retention capacity of the amendment, soil pore water samplers were installed at the site and trace element composition monitored for 12 months.

\section{$2 \quad$ Materials and methods}

\subsection{Field site}

The Collstrop wood impregnation site close to Hillerød, Denmark, has previously been used for soil stabilization with WTR at a small scale [14]. Wood impregnation using As, Cr, and Cu was initiated in 1955. Heavily contaminated with As, $\mathrm{Cr}$, and $\mathrm{Cu}$, the site is left as a brownfield in the forest. A sketch of the site with vegetation cover is presented in Fig 1. A profound correlation between vegetation cover and contaminant concentration was found in an earlier study [20] with only very limited vegetation growing at contamination hotspots. For this experiment a bare dripping pad in the eastern part of the site was chosen as test site. At dripping pads the treated wood items were placed for drying. Fig. 1 shows the configuration of the test site and location of the 10 pore water samplers, more than 40 soil samples and 4 shallow wells.

\subsection{Amendment}

Fe-WTRs were collected at Sjælsø Waterworks in Northern Zealand, Denmark, which supplies water to large parts of the greater Copenhagen area. Groundwater is extracted from wells 50 to $120 \mathrm{~m}$ below surface in a limestone aquifer, and the water is then aerated and passed through a sand filter for separating iron and manganese oxides from the drinking water. Freshly precipitated Fe-WTR slurry with a natural water content $(91.2 \%, \mathrm{n}=5)$ was used as amendment.

Chemical analysis and BET (Brunauer-Emmett-Teller) surface area of the solids can be found in Table 1. For further information on the Fe-WTR composition, we refer to the earlier publication [14]. 


\subsection{Soil mixing procedure at field scale}

Before considering the options for soil mixing, an estimate was made of the volume of soil that needed to be treated at the site. The contaminants originate from dripping of impregnation liquids and as most of the contaminant masses are present in the upper $1 \mathrm{~m}$ of the soil profile [14], an estimated $80 \%$ of the contaminant mass would be captured by treating the upper $1 \mathrm{~m}$ of the soil. Additionally, previous studies at the field site had revealed a hanging water table 1-1.5 m below ground [14]. Adding Fe-WTR below the water table will have little effect, as the highly reactive ferrihydrite is expected to be easily dissolved by reductive dissolution and presumably destroy the effect of the amendment, as the iron oxides are dissolved, releasing all captured contaminants. Thus a treatment depth of 1 meter was chosen. A rotary screening bucket mounted on an excavator was used to mix soil and Fe-WTR slurry. A test field of 10 by $10 \mathrm{~m}$ with amendment of Fe-WTR was established. Adjacent to that a 10 by $10 \mathrm{~m}$ test site without amendment was established, to act as a control plot for the evaluation of the Fe-WTR amendment efficiency. Pore water was also sampled from an undisturbed soil profile within a few meters from the test fields. For configuration of the test fields see Fig. 1. Fig. 2 shows the rotary screening bucket in action.

A slurry-trailer carrying a $4.5 \mathrm{~m}^{3}$ basin, installed with mixers, kept the WTR slurry in suspension to make sure the solids were applied evenly at a rate of $0.12 \mathrm{~m}^{3} \cdot \mathrm{min}^{-1}$. Soil and Fe-WTR was mixed in 2 steps; excavating to $0.5 \mathrm{~m}$ and mixing with half the Fe-WTR slurry, then backfilling and mixing again down to 1 meter depth and adding the other half of the Fe-WTR slurry. A total of $4 \mathrm{~m}^{3}$ was added to the amended field, which was the maximum amount possible to not increase the volume of the stabilized soil significantly. The average added dry Fe-WTR percentage to the dry matter of soil in the $10 \mathrm{~m}$ by $10 \mathrm{~m}$ by 1 $\mathrm{m}$ is estimated to $0.22 \%(\mathrm{dw})$. The control field was also mixed in 2 steps, but with no Fe-WTR addition and therefore more difficult to mix because the slurry made it easier for the soil to pass through the screening bucket.

During mixing greenish colored concrete pieces were separated from the soil, which are likely remains of the impregnation basins and their greenish color presumably copper-arsenate precipitates. For brownfield management, removing waste fractions like this will improve the esthetic value of the site.

\subsection{Sampling and monitoring}

After soil mixing in late April 2011, the site was left to settle. Soil samples were taken at random spots in the amended and the control plots in May 2011. In total nine composite samples representing the depth 00.5 meters depth and 0.5-1 meter depth were sampled for both plots (in total 36 samples). The average composition of the soil in the mixed plot and in the control plot was compared using t-test $(\mathrm{P}=0.05, \mathrm{n}=18)$. Groundwater wells and soil pore water samplers were installed in early May 2011. As according to the manufacturer of samplers the first $2 \mathrm{~L}$ of samples has to be discarded; only samples after June 2011 were analyzed. The experiment was concluded in July 2012 after collecting and analyzing more than 200 water samples. 
To monitor the composition of soil pore water, 10 PrenArt ${ }^{\circledR}$ pore water samplers were installed at an angle of $45^{\circ}$ (to limit rapid flow along the tubing) at depth 0.5 and $1 \mathrm{~m}$ below surface. Each sampler was connected to a $1 \mathrm{~L}$ Bluecap bottle with $1 \mathrm{kPa}$ vacuum. The bottle was changed every 21-31 d, when the collected amount was sufficient for analysis. Total sample volume and $\mathrm{pH}$ were measured and $20 \mathrm{~mL}$ samples were filtered through a $0.45 \mu \mathrm{m}$ hydrophilic PTFE filter and stored at $5^{\circ} \mathrm{C}$ until analysis. The soil pore water concentrations in the amended and the unamended field plot and in an undisturbed reference site a few meters away were sampled over a 14 month period to monitor potential temporal changes. Both test fields were divided in a 3x3 sampling grid (Fig. 1). Soil samples were collected using a hand auger. A 100 g composite sample was taken from each of the $0.5 \mathrm{~m}$ homogenized cores at depths 0-0.5 $\mathrm{m}$ and 0.5-1.0 m. The samples were dried at $105^{\circ} \mathrm{C}$ for $24 \mathrm{~h}$ and homogenized in an agate mortar. From the homogenized sample $2 \mathrm{~g}$ was taken for acid digestion in $7 \mathrm{~N} \mathrm{HNO}_{3}$.

A hanging secondary water table was present at the site due to clay layers in the glaciofluvial formation [14]. At the time of soil mixing in late spring it was observed about 1 meter below the soil surface. To measure the water table 2 shallow wells (PE tubing $\varnothing 2.2 \mathrm{~cm}$ ) were installed by hand augering at $1 \mathrm{~m}$ depth with $20 \mathrm{~cm}$ screen. Water table measurements were done with the same frequency as water sampling.

\subsection{Element analysis of soil and water}

Element content in soil and water samples was determined using a Varian 5000 ICP-OES. A standard reference soil was included for every 30 samples and all measurements of those found to be within $10 \%$. Detection limits for water samples were $0.7 \mu \mathrm{g} \cdot \mathrm{L}^{-1}$ and for soil samples $35 \mathrm{mg} \cdot \mathrm{kg}^{-1}$ at wavelengths 259.940 (Fe) $293.931(\mathrm{Mn}) 327.395(\mathrm{Cu}) 205.560(\mathrm{Cr})$ and $188.980(\mathrm{As}) \mathrm{nm}$.

For the last 3 rounds of pore water sampling the speciation of $\mathrm{Cr}(\mathrm{VI}) / \mathrm{Cr}(\mathrm{III})$ and $\mathrm{As}(\mathrm{V}) / \mathrm{As}(\mathrm{III})$ was measured. Visual light spectrophotometric screening for $\mathrm{Cr}(\mathrm{VI})$ was done using s-diphenylcarbazide as an indicator (EN 196-10:2006, 2006) with at detection limit of $10 \mu \mathrm{g} \cdot \mathrm{L}^{-1}$. As(V)/As(III) speciation was done by filtering through an aluminosilicate-containing cartridge, retaining $\mathrm{As}(\mathrm{V})$ [21]. The $\mathrm{As}(\mathrm{V})$ concentration was then calculated as the difference between As(III) and the total As content.

\subsection{Physical properties of soil and WTR}

BET surface area was measured by the $\mathrm{N}_{2}$ adsorption method [22]. For soil and WTR properties such as geological characterization, grain size and distribution see [14].

\section{$3 \quad$ Results and discussion}

\subsection{Distribution of the amendment}

The analysis of the homogenized core samples showed only a slight difference in iron content with an average of $4815 \mathrm{mgFe} \cdot \mathrm{kg}^{-1}$ (range 1193-6124 $\mathrm{mgFe} \cdot \mathrm{kg}^{-1}$ ) in the control field and $5360 \mathrm{mgFe} \cdot \mathrm{kg}^{-1}$ (range 3805-13304 mgFe $\mathrm{kg}^{-1}$ ) in the amended (Table 1). A difference of $0.13 \mathrm{wt} \%$ Fe was found in the upper 0.5 
$\mathrm{m}$ of soil between the treated and the untreated field and there was no significant ( $t$-test, $\mathrm{P}=0.05, \mathrm{n}=18$ ) difference between iron concentrations in the lower parts of the two fields. The iron amendment was not sufficiently distributed, as the upper $0.5 \mathrm{~m}$ in the treated field has a mean value of $6140 \mathrm{mgFe} \cdot \mathrm{kg}^{-1}$ and the lower only slightly more than the natural background value of $4815 \mathrm{mgFe} \cdot \mathrm{kg}^{-1}$. Iron distribution in soil layers is shown in Fig. 3, which also reveals a high variability in the background level of iron content with high iron content at the bottom of the control field, may be a soil horizon formed by the natural pseudogleyic conditions in the soil.

\subsection{Leaching of contaminants in the amended soil}

Soil pore water concentrations are a tool to evaluate the most mobile fraction of trace elements in soils [23]. Pore water concentrations of As (Fig. $4 b+c$ ), Cr (Fig. 5a+b) and $\mathrm{Cu}($ Fig. $5 c+d$ ) are decreased as the addition of Fe-WTR significantly reduces the mobile fraction of contaminants in the soil. Comparing all data points for the full year of sampling, the soil amendment reduces pore water concentrations in the mixed fields with $93 \%$ for As, 91\% for $\mathrm{Cu}$ and $95 \%$ for $\mathrm{Cr}$ in the shallow (50 cm below ground) samplers and $75 \%$ for As, $89 \%$ for $\mathrm{Cu}$ and $97 \%$ for $\mathrm{Cr}$ in the deeper samplers when comparing with the control site. This difference shows that the upper soil has obtained a larger retention for As and that the lower part of the treated field did not receive a sufficient amount of the Fe-WTR. In terms of the Danish groundwater quality criteria, the dose of Fe-WTR was not sufficient. The average As concentration for amended soil (upper samplers) is $328 \mu \mathrm{g} \cdot \mathrm{L}^{-1}$ and does not comply with the groundwater criteria of $8 \mu \mathrm{g} \cdot \mathrm{L}^{-1}$ [24], but the leaching of contaminants has been significantly reduced. Studies using iron oxide amendment for stabilization has typically used a higher percentage of iron oxides added to the soil to obtain better contaminant retention: 5-15 wt\% [25] or 1-8\% [18] oxygen scarfing granulate (69\% magnetite) or 2.5-5.0 wt\% ochre (likely ferrihydrite, calcite and aragonite) [11]. Average Fe-WTR addition obtained in this full scale study was about $0.22 \mathrm{wt} \%$ of the amended soil. The amendment is to be increased to a range of 1-2 $\mathrm{wt} \%$ in future full scale projects.

\subsection{Speciation of As and $\mathrm{Cr}$}

As toxicity and mobility in soil and groundwater is hugely dependent on speciation, a chemical speciation As and Cr was done in the last 3 rounds of pore water sampling as mentioned in the material and methods section. As no $\mathrm{Cr}(\mathrm{VI})$ was found in the pore water, all chromium at the site is assumed to be $\operatorname{Cr}(\mathrm{III})$ which is consistent with the low solubility of chromium hydroxides in soil [26] and the observed low pore water concentrations. Only two samples contained more than 5\% As(III), which means that the overall speciation of arsenic at the site is consistent with aerobic conditions. These two samples with $8.5 \%$ and $20 \%$ As(III) were from the deep sampler in the untreated field. This correlates well with the fact that the deep samplers at $90 \mathrm{~cm}$ below ground are likely to be below the water table and that this field had the high iron concentrations in the pore water, suggesting somewhat reducing conditions. 


\subsection{Effect of water logged conditions}

Reductive dissolution of iron oxides can happen as the soil gets saturated with water and release of sorbed arsenic takes place accordingly [27-29]. The rate of reductive dissolution of iron (hydr-)oxides depends on mineral type, crystallinity and aggregate size [30,31]. For Fe-WTR amendment the reaction rate is expected to be very high as the main constituent is ferrihydrite, the most reactive iron hydroxide for the above mentioned reasons.

Water table measurements are shown in the top right corner of Fig. 4a, which also shows the total iron concentration of the sampled pore water in Fig $3 \mathrm{~d}+\mathrm{e}$. Only for the unamended field did iron concentrations in the pore water increase (up to around $400 \mu \mathrm{g} \cdot \mathrm{L}^{-1}$ ) in the period from late August to December. Small amounts of iron (up to $100 \mu \mathrm{g} \cdot \mathrm{L}^{-1}$ ) were found after December, despite the water table only slowly decreased during the months of January to March. Temperature dependence of iron reduction rates in soil with the release of Fe and As have been reported to strongly slow down when the temperature decreases from $23^{\circ} \mathrm{C}$ and $14^{\circ} \mathrm{C}$ to $5^{\circ} \mathrm{C}$ [29]. If this is part of the explanation it implies that a coincidence of the cold season with the infiltration season, as seen here, is beneficial where waterlogging may occur.

As no increase in dissolved iron is seen in the iron amended soil, not even during water logging, it suggests that the iron amendment is resistant to iron reducing conditions. Microbial activity in the soil may be low due to the high contents of contaminants [32]. Especially copper has been shown to have a toxic effect on iron reducing bacteria, thereby halting iron reduction [33]. However as the copper concentration is almost identical in the fields, this cannot be the sole explanation. If the reduction of iron oxide in the soil is not complete due to an excess of iron oxide in the soil (which is likely to be the case for the Fe-WTR amended soil), it is possible that iron and arsenic is retained in the soil. $\mathrm{Fe}^{2+}$ competes for arsenate on the ferrihydrite surface [34], so the $\mathrm{Fe}^{2+}$ released by iron reduction may not be released to the water phase in the amended soil. Likewise the release of As to the aqueous phase does not happen until the number of surface sites on the ferrihydrite surface is too small to adsorb all arsenic [28].

Another approach is to study the manganese concentrations in the soil pore water (Fig. $3 \mathrm{f}+\mathrm{g}$ ). FeWTR contains a substantial amount of manganese oxides, precipitated with the iron oxides, and the background concentration of manganese (in average $198 \mathrm{mg} \cdot \mathrm{kg}^{-1}$ ) is relatively smaller compared to the amount of WTR added to the soil. Manganese reduction is thermodynamically favored over iron reduction, so a high porewater concentration of manganese indicates WTR dissolution, as can be seen in Fig. 3, where a peak in the Mn concentration is correlated with a high water table (Fig. 4a).

\subsection{Mechanical treatment of soil}

Based on the As and Fe (Fig. 4bcde) as well as the $\mathrm{Cr}$ and $\mathrm{Cu}$ (Fig. 5abcd) pore water concentrations, the mechanical treatment of mixing the soil without adding Fe-WTR has a significant effect on the levels of all measured elements in the soil pore water. This indicates that the mixing of contaminated soil increases the leaching of elements, possibly due to release of fine colloids mobilized with the mechanical treatment of the soil. Addition of iron oxides to a soil do change the mechanical properties of soil and ferrihydrite, the 
main constituent of Fe-WTR, has even been proposed as a clearing agent to reduce turbidity in fresh water [35]. A cementing effect of Fe-WTR may limit the colloidal transport of elements and this effect can account for some of the difference in metal(loid) leaching in the two mechanically treated fields. This observation suggest that the mechanical treatment of soil, for instance in the case of excavation and landfilling, may increase the leaching of contaminants, but this effect can be avoided with the addition of Fe-WTR.

\section{Conclusions}

Stabilization with Fe-WTR in full scale proved to be fairly simple to apply to the contaminated site. Despite insufficient application of amendment, the field experiment provides valuable insight in the practical application of an iron oxide based soil amendment. Leaching of $\mathrm{As}$, $\mathrm{Cr}, \mathrm{Cu}$, as measured by pore water concentrations, was significantly reduced in the Fe-WTR amended soil compared to both a mechanically mixed, but not amended, soil and an undisturbed soil. Even with an iron addition of only 0.22 $\mathrm{wt} \%$, the amendment caused a significant stabilization, but more Fe-WTR than applied in this study is needed to comply with ground water quality standards. Despite water logged conditions in the lower parts of the soil, no clear signs of iron reduction and subsequent contaminant release were observed. Manganese was however released from the treated soil, suggesting that the Fe-WTR is subject to partial reductive dissolution.

The distribution of soil amendment achieved with a screening bucket was satisfying for the upper part of the soil, but it proved more difficult, at least in this very first attempt, to amend the soil from 0.5 to $1 \mathrm{~m}$ below surface. In any case, mechanical treatment or mixing of metal(loid) contaminated soil should be avoided as it mobilizes dissolved (or colloidally transported) contaminants into the soil pore water. However Fe-WTR treatment prevents this, possibly because of inter-particulate cementation processes. As the dose of WTR and difficulties with proper mixing are rather easy obstacles to overcome, we propose this method for use in situ at other contaminated sites.

Acknowledgements This research is part of the research project Innovative Remediation and Assessment Technologies for Contaminated Soil and Groundwater (REMTEC). The authors would like to thank Sinh Hy Nguyen and Susanne Kruse for technical support and Lisbet Brusendorff for graphical assistance. As site owner Naturstyrelsen, represented by forest manager Hans Holbech, is acknowledged for admission at the Collstrop site.

\section{References}

1. Amofah L R, Maurice C, Bhattacharya P. Extraction of arsenic from soils contaminated with wood preservation chemicals. Soil \& Sediment Contamination, 2010, 19: 142-159

2. Buchireddy P R, Bricka R, Gent D B. Electrokinetic remediation of wood preservative contaminated soil containing copper, chromium, and arsenic. Journal of Hazardous Materials, 2009, 162: 490-497 
3. Kertulis-Tartar G, Ma L, Tu C, Chirenje T. Phytoremediation of an arsenic-contaminated site using Pteris vittata L.: A two-year study. International Journal of Phytoremediation, 2006, 8: 311-322

4. Rivett M O, Petts J, Butler B, Martin I. Remediation of contaminated land and groundwater: experience in England and Wales. Journal of Environmental Management, 2002, 65: 251-268

5. Kumpiene J, Lagerkvist A, Maurice C. Stabilization of As, $\mathrm{Cr}, \mathrm{Cu}, \mathrm{Pb}$ and $\mathrm{Zn}$ in soil using amendments - A review. Waste Management, 2008, 28(1): 215-225

6. Nagar R, Sarkar D, Makris K C, Datta R, Sylvia V L. Bioavailability and bioaccessibility of arsenic in a soil amended with drinking-water treatment residuals. Archives of Environmental Contamination and Toxicology, 2009, 57: 755-766

7. Lund U, Fobian A. Pollution of 2 soils by arsenic, chromium and copper, Denmark. Geoderma, 1991, 49: 83-103

8. Bhattacharya P, Mukherjee A B, Jacks G, Nordqvist S. Metal contamination at a wood preservation site: characterisation and experimental studies on remediation. Science of the Total Environment, 2002, 290: $165-180$

9. Miretzky P, Cirelli A F. Remediation of arsenic-contaminated soils by iron amendments: A review. Critical Reviews in Environmental Science and Technology, 2010, 40: 93-115

10. Komarek M, Vanek A, Ettler V. Chemical stabilization of metals and arsenic in contaminated soils using oxides - A review. Environmental Pollution, 2013, 172: 9-22

11. Doi M, Warren G, Hodson M E. A preliminary investigation into the use of ochre as a remedial amendment in arsenic-contaminated soils. Applied Geochemistry, 2005, 20: 2207-2216

12. Gonzalez V, Garcia I, Del Moral F, Simon M. Effectiveness of amendments on the spread and phytotoxicity of contaminants in metal-arsenic polluted soil. Journal of Hazardous Materials, 2012, 205: 72-80

13. Sarkar D, Makris KC, Vandanapu V, Datta R. Arsenic immobilization in soils amended with drinkingwater treatment residuals. Environmental Pollution, 2007, 146: 414-419

14. Nielsen SS, Petersen LR, Kjeldsen P, Jakobsen R. Amendment of arsenic and chromium polluted soil from wood preservation by iron residues from water treatment. Chemosphere, 2011, 84: 383-389

15. Chiang Y, Santos R, Ghyselbrecht K, Cappuyns V, Martens J, Swennen R, Van Gerven T, Meesschaert B. Strategic selection of an optimal sorbent mixture for in-situ remediation of heavy metal contaminated sediments: Framework and case study. Journal of Environmental Management, 2012, 105: 1-11

16. Kumpiene J, Fitts J P, Mench M. Arsenic fractionation in mine spoils 10 years after aided phytostabilization. Environmental Pollution, 2012, 166: 82-88

17. Nielsen S S, Kjeldsen P, Hansen H C B, Jakobsen R. Transformation of natural ferrihydrite aged in As, $\mathrm{Cr}$ and $\mathrm{Cu}$ contaminated soil studied by reduction kinetics. Applied Geochemistry, 2014, 51: 293-302

18. Lidelow S, Ragnvaldsson D, Leffler P, Tesfalidet S, Maurice C. Field trials to assess the use of ironbearing industrial by-products for stabilisation of chromated copper arsenate-contaminated soil. Science of the Total Environment, 2007, 387: 68-78

19. Fjordbøge AS, Riis C, Christensen AG, Kjeldsen P. ZVI-Clay remediation of a chlorinated solvent source zone, Skuldelev, Denmark: 1. Site description and contaminant source mass reduction. Journal of Contaminant Hydrology, 2012, 140: 56-66

20. Samfundsteknik. Kemikalieaffaldsdepot 219-3 Stenholtsvang. Forureningsundersøgelse, Fase 2 (in Danish) English title: Chemical waste facility 219-3 Stenholtsvang Survey of pollution, Phase 2, 1989.

21. Meng X, Wang W. Speciation of arsenic by disposable cartridges. IN: Proceedings - Third International Conference on Arsenic Exposure and Health Effects, San Diego, CA, July 12-15, 1998

22. Brunauer S, Emmett P H, Teller E. Adsorption of gases in multimolecular layers. Journal of the American Chemical Society, 1938, 60: 309-319

23. Moreno-Jimenez E, Beesley L, Lepp N W, Dickinson N M, Hartley W, Clemente R. Field sampling of soil pore water to evaluate trace element mobility and associated environmental risk. Environmental Pollution, 2011, 159: 3078-3085

24. Danish EPA. Liste over kvalitetskriterier i relation til forurenet jord og kvalitetskriterier for drikkevand (in Danish) English title: List of criteria in relation to polluted soil and criteria for drinking water, 2010, Copenhagen, Denmark

25. Maurice C, Lidelow S, Gustavsson B, Lattstrom A, Ragnvaldsson D, Leffler P, Lovgren L, Tesfalidet S, Kumpiene J. Techniques for the stabilization and assessment of treated copper-, chromium-, and arsenic-contaminated soil. Ambio, 2007, 36: 430-436

26. Fendorf S E. Surface-reactions of chromium in soils and waters. Geoderma, 1995, 67: 55-71

27. Islam F S, Gault A G, Boothman C, Polya D A, Charnock J M, Chatterjee D, Lloyd J R. Role of metalreducing bacteria in arsenic release from Bengal delta sediments. Nature, 2004, 430:68-71 
354

28. Pedersen H D, Postma D, Jakobsen R. Release of arsenic associated with the reduction and transformation of iron oxides. Geochimica et Cosmochimica Acta, 2006, 70: 4116-4129

29. Weber F A, Hofacker A F, Voegelin A, Kretzschmar R. Temperature dependence and coupling of iron and arsenic reduction and release during flooding of a contaminated soil. Environmental Science \& Technology, 2010, 44: 116-122

30. Larsen O, Postma D. Kinetics of reductive bulk dissolution of lepidocrocite, ferrihydrite, and goethite. Geochim Cosmochim Acta, 2001, 65: 1367-1379

31. Larsen O, Postma D, Jakobsen R. The reactivity of iron oxides towards reductive dissolution with ascorbic acid in a shallow sandy aquifer - (Romo, Denmark). Geochimica et Cosmochimica Acta, 2006, 70: 4827-4835

32. Turpeinen R, Kairesalo T, Haggblom M M. Microbial community structure and activity in arsenic-, chromium- and copper-contaminated soils. FEMS Microbiology Ecology, 2004, 47: 39-50 11

33. Markwiese J T, Colberg P J S. Bacterial reduction of copper-contaminated ferric oxide: Copper toxicity and the interaction between fermentative and iron-reducing bacteria. Archives of Environmental Contamination and Toxicology, 2000, 38: 139-146

34. Appelo, C A J, Van der Weiden M J J, Tournassat C, Charlet L. Surface complexation of ferrous iron and carbonate on ferrihydrite and the mobilization of arsenic. Environmental Science \& Technology, 2002, 36: 3096-3103

35. Rhoton F E, Bigham J M. Natural Ferrihydrite as an agent for reducing turbidity caused by suspended clays. Journal of Environmental Quality, 2009, 38: 1887-1891 
377 Tables

378

379 Table 1 Average solid concentrations and BET surface area of soil and Fe-WTR and average speciation of

380 pore water in the amended field, control field and undisturbed soil. Number of samples, $n$, are given in

381 parenthesis). For pore water numbers in parenthesis are lowest and highest measured value of As(III) in

$382 \mu \mathrm{g} \cdot \mathrm{L}^{-1}$. Basic soil properties are given in [Error! Bookmark not defined.].

\begin{tabular}{|c|c|c|c|c|c|c|c|c|c|}
\hline & & As & $\mathrm{Cr}$ & $\mathrm{Cu}$ & Mn & $\mathrm{Fe}$ & $\mathrm{BET}$ & As(III)/As(V) & $\mathrm{Cr}(\mathrm{III}) / \mathrm{Cr}(\mathrm{VI})$ \\
\hline & & \multicolumn{4}{|c|}{$\left[\mathrm{mg} \cdot \mathrm{kg}^{-1}\right]$} & {$\left[\mathrm{mg} \cdot \mathrm{kg}^{-1}\right]$} & {$\left[\mathrm{m}^{2} \cdot \mathrm{g}^{-1}\right]$} & \multicolumn{2}{|c|}{$[-]$} \\
\hline \multirow{2}{*}{$\begin{array}{l}\text { Amended } \\
\text { field }\end{array}$} & $\begin{array}{l}0-0.5 \mathrm{~m} \\
(n=9)\end{array}$ & 563 & 205 & 598 & 325 & 6140 & 1.654 & \multirow[b]{2}{*}{$\begin{array}{c}2.3(0.1-3.7) \\
\quad(n=7)\end{array}$} & \multirow[b]{2}{*}{$\begin{array}{l}>99.9 \\
(n=7)\end{array}$} \\
\hline & $\begin{array}{l}0.5-1 \mathrm{~m} \\
(n=9)\end{array}$ & 430 & 133 & 423 & 227 & 4580 & 1.632 & & \\
\hline \multirow{2}{*}{ Control field } & $\begin{array}{l}0-0.5 \mathrm{~m} \\
(n=9)\end{array}$ & 539 & 156 & 378 & 198 & 4830 & 1.859 & \multirow{2}{*}{$\begin{array}{c}11.1(4.2-20) \\
\quad(n=3)\end{array}$} & \multirow{2}{*}{$\begin{array}{l}>99.9 \\
(n=3)\end{array}$} \\
\hline & $\begin{array}{l}0.5-1 \mathrm{~m} \\
(n=9)\end{array}$ & 572 & 149 & 386 & 189 & 4800 & 1.911 & & \\
\hline \multicolumn{2}{|l|}{$\begin{array}{l}\text { Undisturbed } \\
\text { field }\end{array}$} & - & - & - & - & - & - & $\begin{array}{c}1.2(0.4-3.5) \\
(n=4)\end{array}$ & $\begin{array}{l}>99.9 \\
(n=4)\end{array}$ \\
\hline Fe-WTR & $(n=5)$ & 46.1 & $13.0 *$ & 36.6 & 8489.8 & $28.6 \%$ & 160.3 & - & - \\
\hline
\end{tabular}

*below analytical quantification limit - not measured 


\section{$391 \quad$ Figure captions}

392

393

394

395

396

397

398

399

400

401

402

403

404

405

406

407

408

409

410

411

412

413

414

415

416

Fig. 1 Sketch of vegetation Collstrop Brownfield, a former wood impregnation plant. Vegetation is drawn based on observations from [Error! Bookmark not defined.], but is generally in agreement with author observation within recent years (left). Configuration of the full scale soil stabilization experiment with location of pore water samplers, shallow wells and soil samples. Two soil samples were taken at each sampling point (top right) .

Fig. 2 Pictures from the amendment action showing the used rotary screening bucket.

Fig. 3 Total iron concentration in the two test fields after application of water treatment residues (WTR) amendment to the northern field. The size of the bubble denotes the iron concentration

Fig. 4 Soil pore water concentrations of redox sensitive elements $A s(b+c), F e(c+d)$ and $M n(e+f)$ and average water table (a). Left column shows pore water samplers in $50 \mathrm{~cm}$ depth and the right $100 \mathrm{~cm}$ depth. Data points are average of two samplers for elements and four for the water table. Error bars denotes the high and low value. If no error bars are shown, the data point consists of a single measurement from one sampler

Fig. 5 Soil pore water concentrations of $\mathrm{Cr}(\mathrm{a}+\mathrm{b})$ and $\mathrm{Cu}(\mathrm{c}+\mathrm{d})$. Data points are average of two samplers. Error bars denotes the high and low value. If no error bars are shown, the data point consists of a single measurement from one sampler 


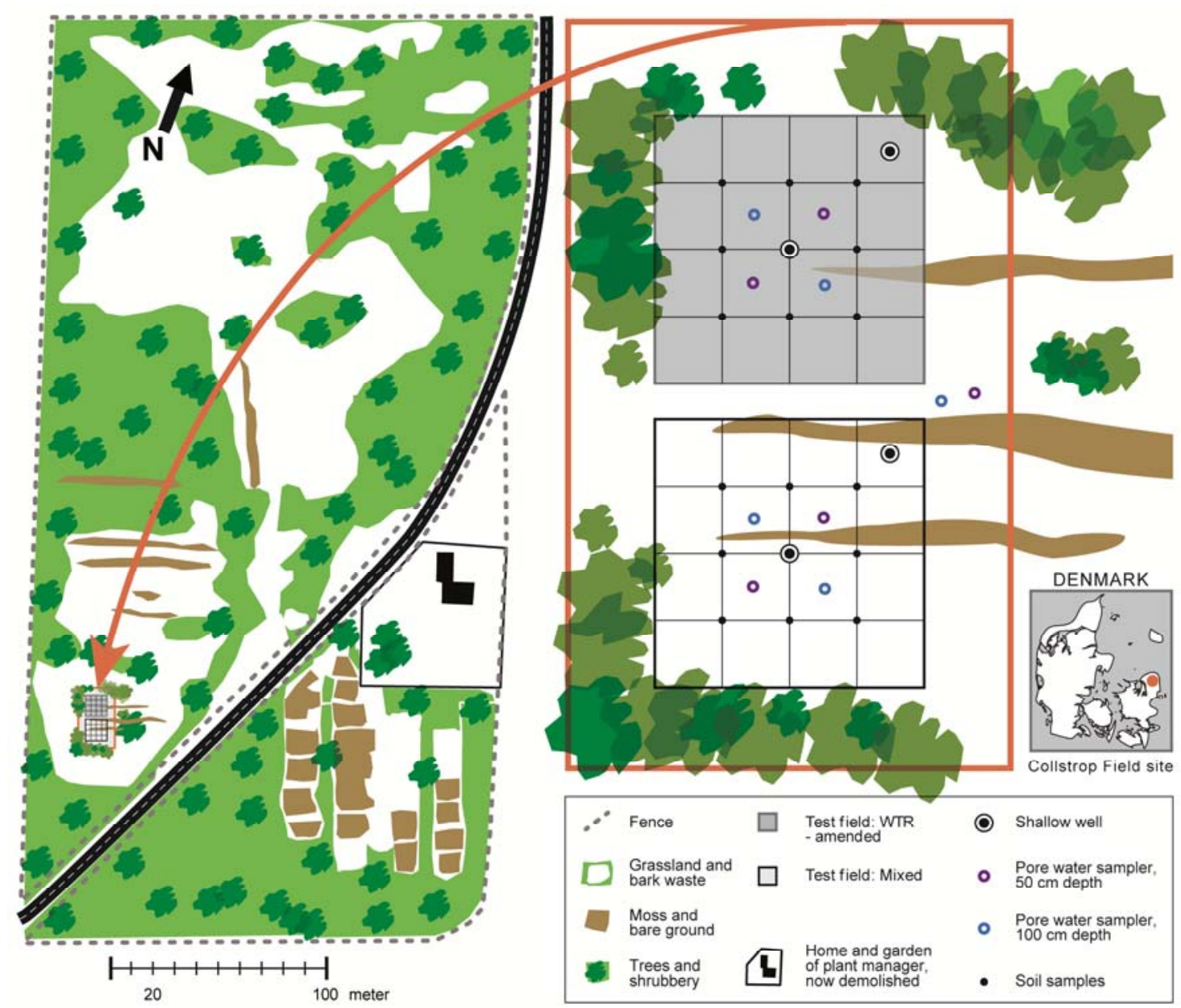

Fig.1 


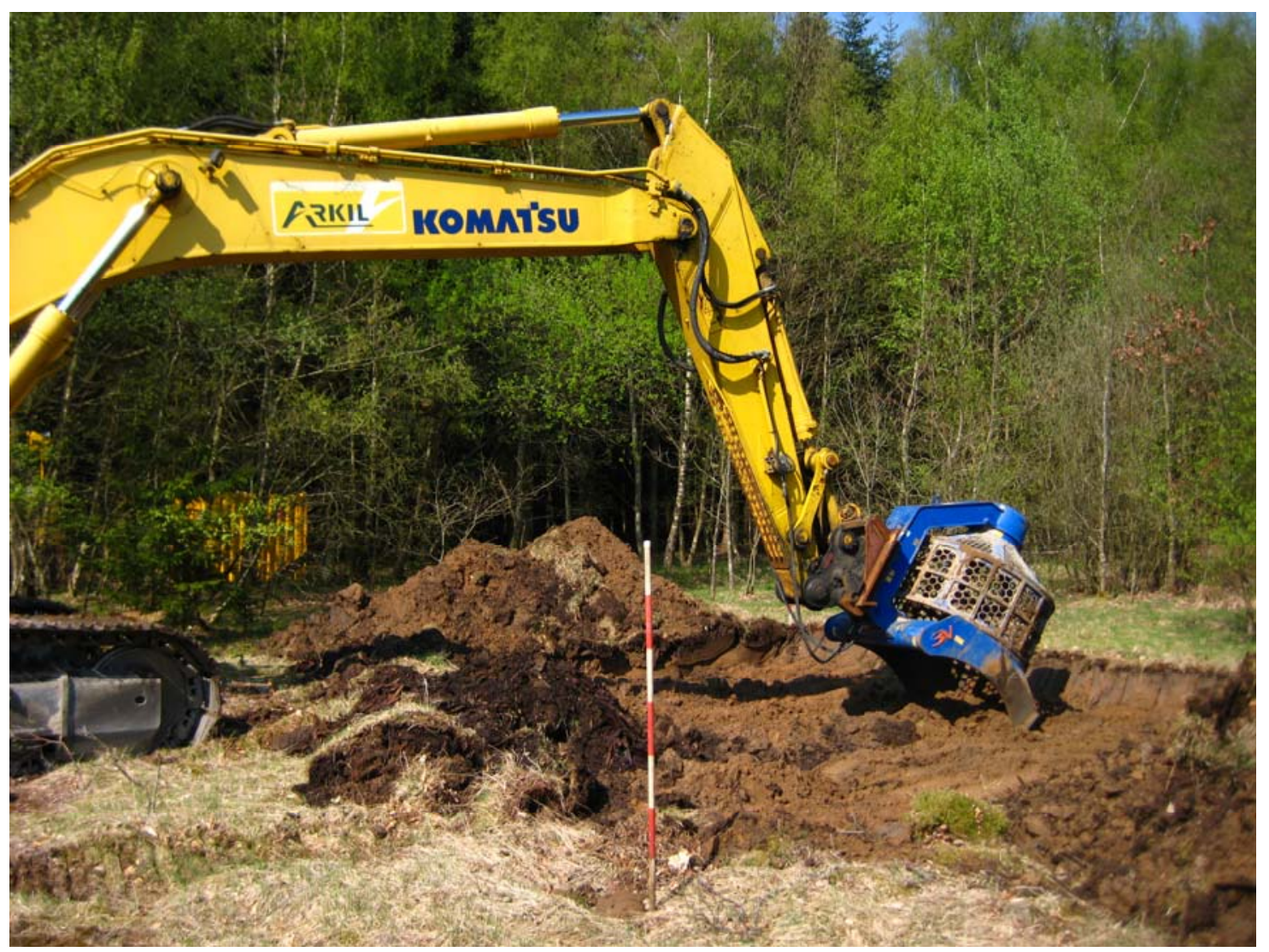

421

Fig. 2a

422 


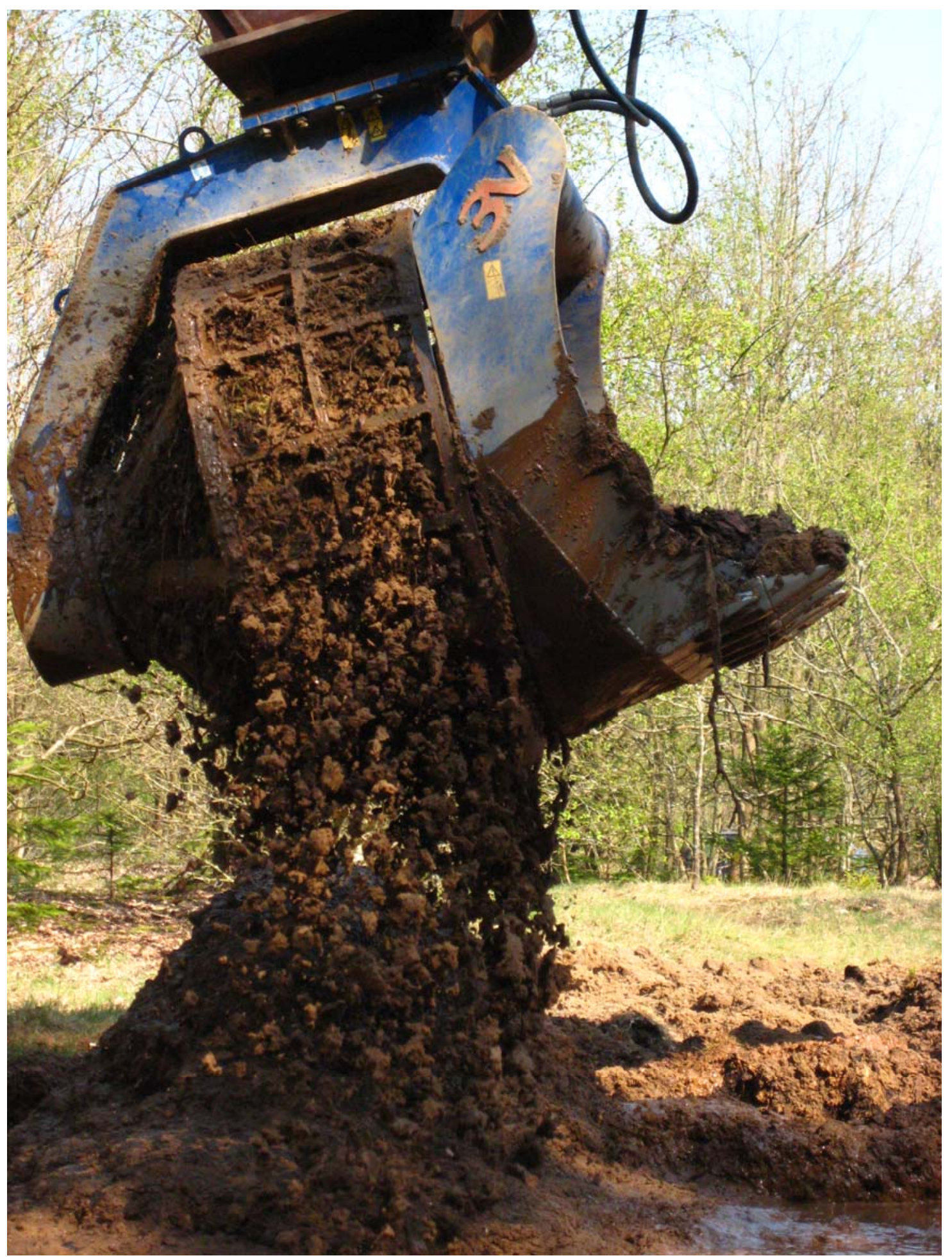



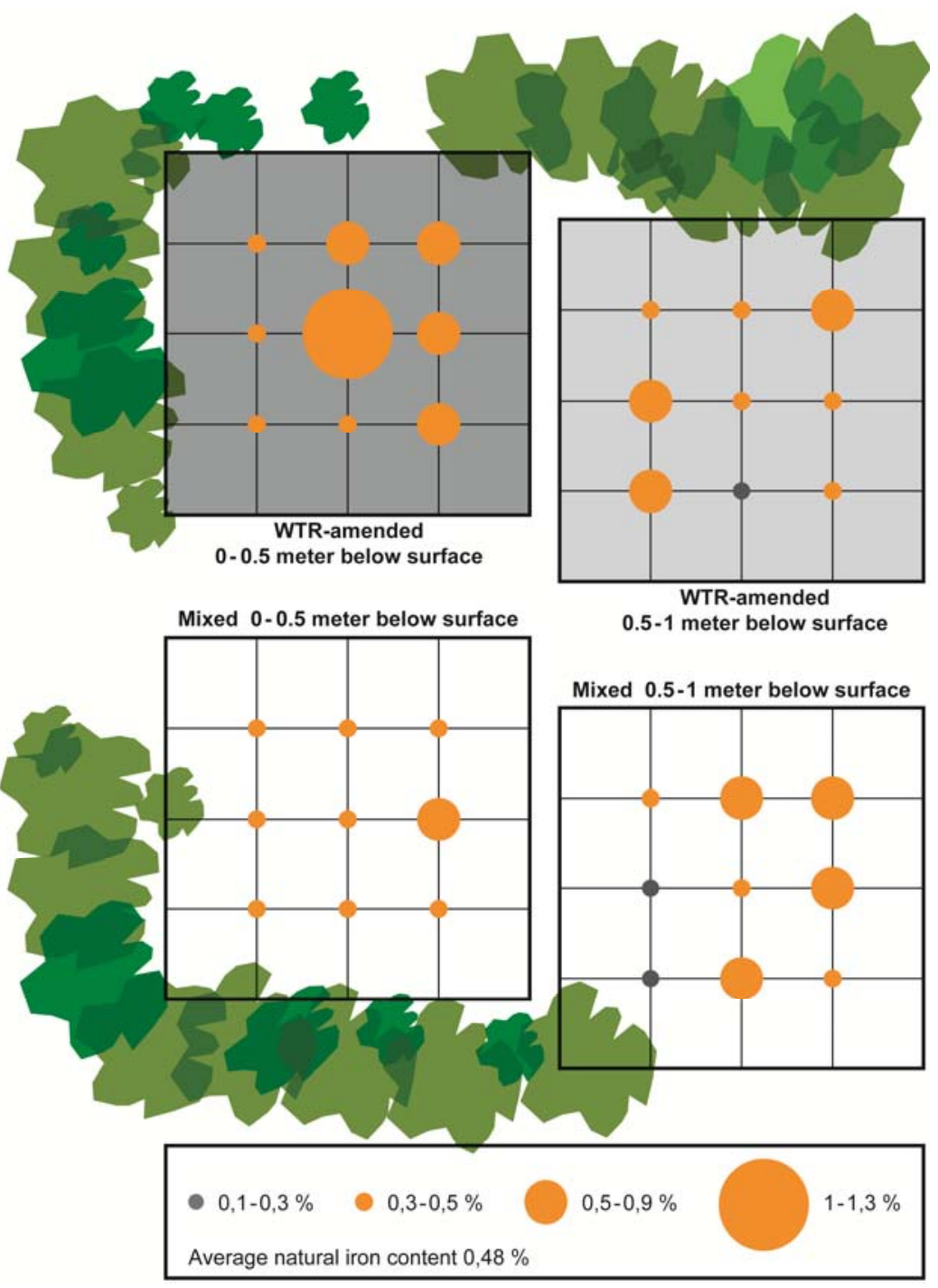

Fig. 3 

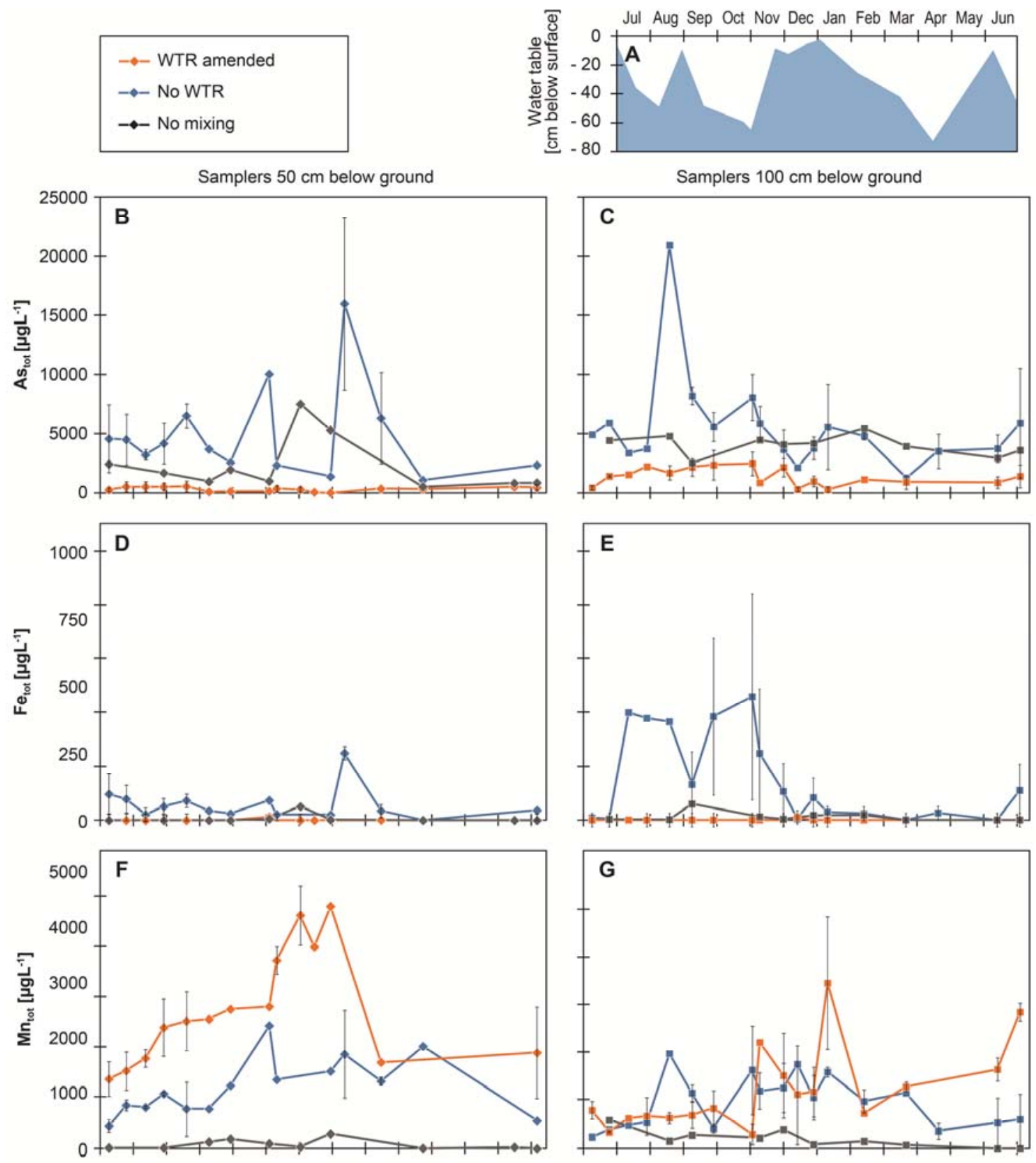

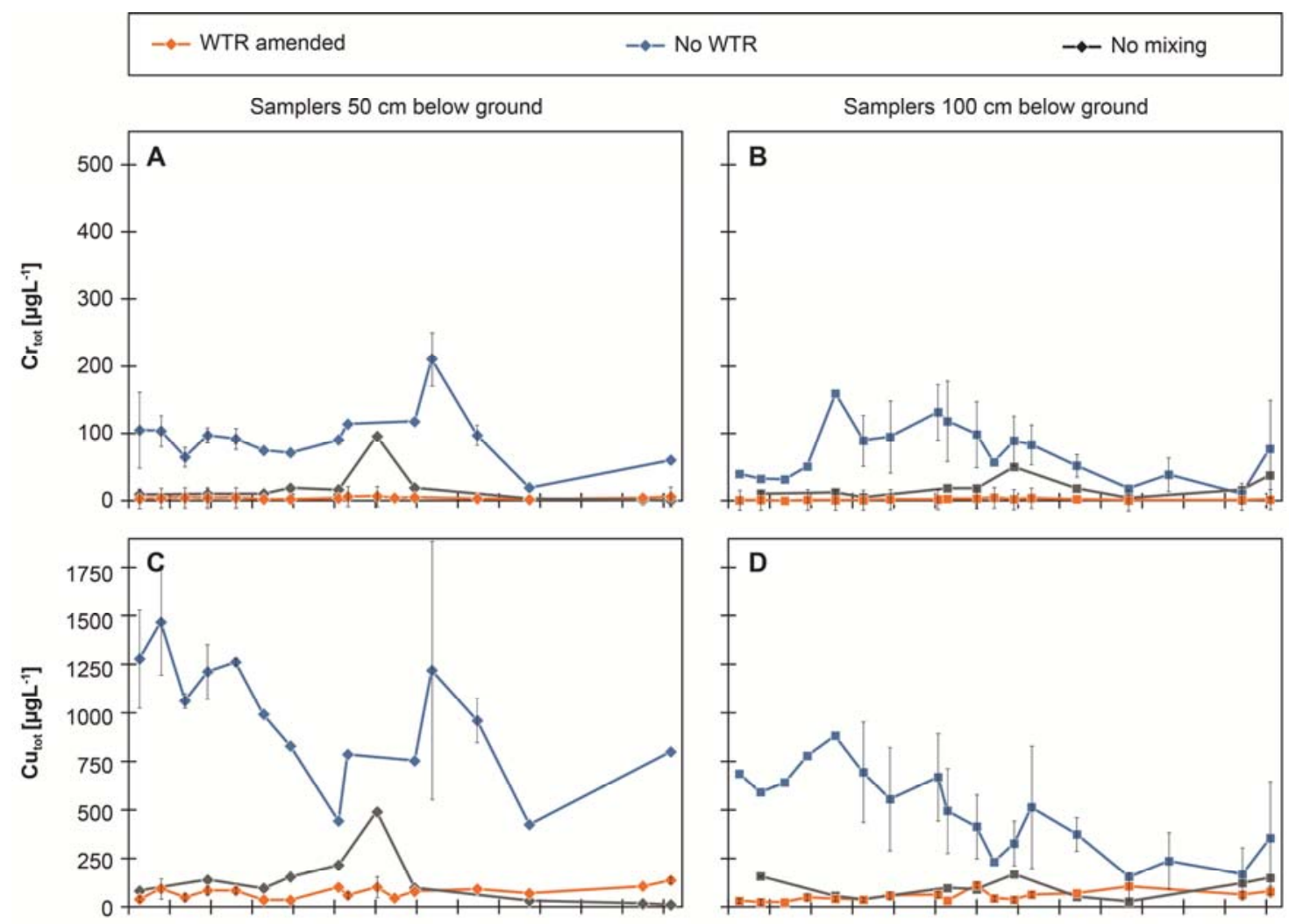

Fig. 5 